\title{
PERTUMBUHAN DAN PRODUKSI BEBERAPA GENOTYPE JAGUNG (Zea mays L.) CALON HIBRIDA UMUR GENJAH DAN VARIETAS PEMBANDING BIMA 7 PADA JARAK TANAM YANG BERBEDA
}

\section{(Growth and Production of Some Maize (Zea mays L.) Genotypes Early Maturing Hybrid Candidate and Varieties Comparison Bima 7 on Different Plant Spacing)}

\author{
Sulkifli $^{1}$, Nirwana ${ }^{1}$ dan Abdul Haris ${ }^{1}$ \\ ${ }^{1}$ Fakultas Pertanian Universitas Muslim Indonesia Makassar \\ Jalan Urip Sumoharjo Km 5 Panakukang, Makassar 90231 Telp. (0411) 455666 \\ E-mail : sulkifliamiruddin@gmail.com
}

\begin{abstract}
This research was conducted with the aim of: 1) To observe growth and production of maize genotypes hybrid candidate early age, 2) Determine optimal spacing that will result in maximal production of genotype hybrid candidate early maturing and 3) To know interaction between maize genotypes hybrid candidate of early maturing and plant spacing. Research was conducted on dry land located in Bajeng, Gowa, South Sulawesi. Research was conducted from April to July 2017 using Split Plot Design method. As the main plot is the maize genotype consisting of 3 genotypes: ST201328, ST201359, ST201312 and varieties comparison Bima 7 while for sub plot is treatment the various spacing between two levels are: $60 \mathrm{~cm} \times 20 \mathrm{~cm}$ and $50 \mathrm{~cm} \times 20 \mathrm{~cm}$. Treatment combination was repeated three times as a block to obtain 24 experimental units. The results of this research show that: 1) Maize genotype ST201328 is maize early maturing hibrid has appearance shortest plant, fastest flowering male age as well flowering female, smallest Anthesis Silking Interval (ASI), fastest harvest age and longer cob. Genotype ST201312 has appearance highest plant, greatest Anthesis Silking Interval, greatest Leaf Area Index and longest cob. 2) Plant spacing $50 \mathrm{~cm}$ x $20 \mathrm{~cm}$ obtained high Leaf Area Index and highest location cob. Average highest production dry seeds on plant spacing $50 \mathrm{~cm} x 20 \mathrm{~cm}$ for all maize genotypes tested. 3) Interaction that happaned between maize genotype ST201312`on plant spacing 60 $\mathrm{cm} \times 20 \mathrm{~cm}$ obtained longest cob is 18,07 cm and differs markedly with varieties comparison Bima 7. Maize genotype ST201312 on plant spacing $50 \mathrm{~cm} \times 20 \mathrm{~cm}$ obtained yield dry cheeks is amount 10,58 ton $h a^{-1}$.
\end{abstract}

Keywords: early maturity, genotypes, hybrid candidate, maize, plant spacing, population

\section{PENDAHULUAN}

Jagung (Zea mays L.) menempati urutan ketiga setelah padi dan gandum dalam produksi biji - bijian pangan dunia. Jagung sebagai sumber utama karbohidrat dan protein setelah beras dan gandum, disamping itu jagung juga berperan sebagai bahan baku industri pangan, industri pakan dan bahan bakar. Permintaan jagung di negara - negara berkembang diprediksi menjadi sekitar
504 juta ton juta pada tahun 2020 dan ini diperkirakan akan melebihi permintaan untuk gandum dan beras (IFPRI, 2000). Produksi jagung nasional tahun 2014 sebesar 19 ton terjadi peningkatan produksi 3,11\% pada tahun 2015 menjadi 19,61 juta ton (Wicaksono, 2015).

Kebutuhan jagung di Indonesia diproyeksikan sebesar 21,35 juta ton pada tahun 2017, dengan peningkatan produksi 
jagung 3,11\% setiap tahun maka prediksi produksi jagung nasional 20,83 juta ton pada tahun 2017 belum memenuhi kebutuhan jagung nasional karena masih kurang 520 ribu ton produksi jagung pipilan kering (Kementrian Perindustrian, 2016). Pemanfaatan jagung sebagai sumber pangan menurun, tetapi dalam perkembangan ekonomi nasional, permintaan jagung khususnya untuk industri pakan ternak terus meningkat dengan pesat. Menurut Suryana, dkk (2005), dalam beberapa tahun terakhir proporsi penggunaan jagung oleh industri pakan telah mencapai $50 \%$ dari total kebutuhan nasional. Dalam 20 tahun ke depan, penggunaan jagung untuk pakan diperkirakan terus meningkat dan bahkan setelah tahun 2020 penggunaan jagung untuk kebutuhan pakan diperkirakan lebih dari $60 \%$ dari kebutuhan nasional. Produksi jagung di Sulawesi Selatan pada tahun 2014 sebanyak 1,49 juta ton pipilan kering yang diperoleh dari luas panen 289,74 ribu hektar dan tingkat produktifitas 51,46 kuintal per hektar dan pada tahun 2015 produksi jagung sebanyak 1,53 juta ton pipilan kering, mengalami kenaikan sebanyak 37,42 ribu ton $(2,51 \%)$ dibandingkan tahun 2014. Kenaikan produksi terjadi karena kenaikan luas panen seluas 5,38 ribu hektar $(1,86 \%)$ dan produktifitas sebesar 33 kuintal per hektar $(0,64 \%)$ (BPS, 2016). Kebutuhan jagung semakin meningkat maka upaya peningkatan produksi jagung dapat dilakukan melalui ekstensifikasi dan intensifikasi.

Ekstensifikasi telah dilakukan di Sulawesi Selatan tetapi hanya terjadi kenaikan sebanyak 37,42 ribu ton $(2,51 \%)$ produksi. Kendala utama peningkatan produksi jagung adalah konversi lahan subur untuk kepentingan nonpertanian yang terus berlangsung, seperti; perumahan, industri, bisnis dan infrastruktur. Konsekuensinya adalah kebutuhan lahan untuk pertanian hanya dapat dipenuhi melalui pemanfaatan lahan-lahan suboptimal yang pada umumnya miskin hara dan sering dilanda kekeringan (Adger et al., 2005). Selain itu, perubahan iklim global (climate change) juga merupakan salah satu ancaman terhadap kelangsungan produksi jagung (Subaedah et al., 2015). Perubahan iklim akan berdampak terhadap peningkatan suhu (global warming) yang diikuti oleh banjir dan kemarau yang ekstrem. Perubahan lainnya yang akan berpengaruh terhadap kegiatan budidaya pertanian adalah pergeseran distribusi hujan yang 
semakin sulit diprediksi, sehingga al., 1998). Maka perlu dilakukan penentuan waktu tanam sulit dilakukan pengujian beberapa genotype jagung calon dan resiko gagal panen semakin besar hibrida umur genjah untuk meningkatkan (Balitbang Pertanian 2011). Kendala produksi jagung per satuan luas dengan pengembangan jagung kedepan meningkatkan populasi tanaman jagung sebagaimana diuraikan sebelumnya hingga batas optimum. Pengaturan jarak merupakan tantangan menghasilkan tanam merupakan salah satu teknik inovasi teknologi baru. Dengan budidaya yang dapat digunakan untuk memaksimalkan produktifitas jagung meningkatkan produksi sesuai dengan melalui intensifikasi. Intensifikasi pernyataan Suprapto dan Nyoman (2000), merupakan upaya peningkatan mutu dan untuk meningkatkan produktivitas pada produksi yang dilakukan yaitu memilih kondisi lingkungan yang ekstrem perlu varietas unggul yang mampu beradaptasi dilakukan, seperti pemakaian varietas dengan perubahan iklim. Varietas unggul tanaman unggul berumur genjah dan baru yang berpeluang besar untuk penerapan jarak tanam yang sesuai dengan mengantisipasi perubahan iklim adalah curah hujan. Menurut Gardner et al. jagung hibrida umur genjah yang (1996), pengaturan jarak tanam bertujuan berpotensi hasil tinggi (Subaedah et al., untuk meminimalkan kompetisi 2016). Jagung umur genjah juga sesuai intrapopulasi agar kanopi dan akar dikembangkan pada daerah yang memiliki tanaman dapat memanfaatkan lingkungan masa pertanaman pendek, pada lahan secara optimal. Sumarni et al. (2012), sawah tadah hujan, dan bermanfaat untuk menyatakan jarak tanam berhubungan meningkatkan indeks pertanaman (Azrai, sangat erat dengan populasi tanaman per 2013). Varietas jagung hibrida umur genjah dapat diperoleh dari hasil seleksi dan penyaringan kemampuan genotype genotype jagung.

Pada umumnya tanaman berumur genjah mempunyai tanggapan lebih baik terhadap kepadatan populasi (Sudjana et satuan luas. Semakin rapat jarak tanam semakin banyak populasi. Pada kondisi seperti ini kemungkinan terjadinya persaingan semakin besar dalam hal mendapatkan faktor - faktor tumbuh (CO2, cahaya, air dan udara) dan dapat berpengaruh terhadap pertumbuhan dan produksi tanaman. Jarak tanam yang lebar 
populasinya semakin sedikit, tidak efesien dalam pemanfaatan lahan, terjadi kebocoran energi matahari, tanah terbuka sehingga memacu pertumbuhan gulma mengakibatkan produktifitas rendah (Resiworo, 2012). Oleh karena itu, jarak tanam harus diatur untuk mendapatkan populasi yang optimum sehingga dapat diperoleh hasil yang maksimum.

\section{METODE PENELITIAN}

Penelitian dilakukan di Lahan Kering yang berlokasi di Bajeng, Gowa, Sulawesi Selatan. Penelitian dilaksanakan mulai 19 April sampai 29 Juli 2017. Bahan tanaman yang digunakan dalam penelitian ini adalah benih jagung calon hibrida dari 3 genotype yaitu; Genotype ST201328, Genotype ST201359, Genotype ST201312 dan varietas pembanding Bima 7. Bahan lain yang digunakan meliputi; pupuk kandang, urea $(45 \%$ N), NPK Phonska (15\% N, 15\% $\mathrm{P} 2 \mathrm{O} 5,15 \% \mathrm{~K} 2 \mathrm{O}$ dan $10 \% \mathrm{~S}$ ), dengan dosis masing - masing $150 \mathrm{~kg} \mathrm{ha}^{-1}$ dan $150 \mathrm{~kg} \mathrm{ha}^{-1}$. Untuk pengendalian hama dan penyakit digunakan pestisida sedangkan pengendalian gulma digunakan herbisida (calaris). Alat - alat yang digunakan diantaranya adalah alat pertanian sederhana (cangkul, kored, tugal, arit, garu dan ajir), label, tali, mistar geser, meteran, kertas label, timbangan analitik, oven, knapsack sprayer dan lain lain. Penelitian ini menggunakan Rancangan Split Plot Design terdiri dari petak utama dan anak petak. Sebagai petak utama adalah perlakuan genotype jagung (G) yang terdiri dari 4 yaitu; ST201328 (G1), ST201359 (G2), ST201312 (G3) dan Varietas Bima 7 (G4). Sebagai anak petak adalah perlakuan jarak tanam $(\mathrm{J})$ yang terdiri dari 2 taraf yaitu; Jarak Tanam $60 \mathrm{~cm} \mathrm{x} 20 \mathrm{~cm}$ (J1) dan Jarak Tanam $50 \mathrm{~cm} \times 20 \mathrm{~cm}$ (J2)Kedua Faktor yang diuji menghasilkan 8 kombinasi perlakuan. Kombinasi perlakuan diulang sebanyak tiga kali sebagai blok sehingga diperoleh 24 unit percobaan. Pelaksanaan Penelitian yang pertama dilaksanakan adalah Pengolahan tanah, dengan cara membajak tanah dua kali kemudian dilakukan penggaruan untuk menghancurkan bongkahan tanah dan dilakukan perataan serta rotari untuk lebih memperhalus tekstur tanah, kemudian lahan dibagi dalam 3 blok sebagai kelompok, kemudian setiap blok dibagi menjadi 4 petak utama yang berukuran $4,5 \mathrm{~m}$ x $3 \mathrm{~m}$ selanjutnya petak utama dibagi menjadi 2 anak petak yang berukuran $2 \mathrm{~m} \quad \mathrm{x} \quad 3 \mathrm{~cm}$. Penanaman 
dilakukan dengan membuat lubang tanam sedalam $3-4 \mathrm{~cm}$, tiap lubang tanam ditanami 2 benih jagung dengan jarak tanam yang disesuaikan dengan ketentuan perlakuan. Pemeliharaan yang dilakukan ke tanaman jagung pada saat penelitian yaitu; pengairan, penyulaman, pemupukan, penyiangan, pembumbunan dan penjarangan. Pemanenan dilakukan pada saat tanaman berumur \pm 90 hari setelah tanam. Tanaman jagung dapat dipanen setelah biji pada tongkol mencapai matang fisiologis dengan kriteria panen rambut (silk) berwarna coklat kehitaman (black layer) dan telah mengering, kelobot berwarna kuning, daun tanaman telah menguning, biji kering dan mengkilat dan jika ditekan dengan kuku tidak meninggalkan bekas. Setelah panen, dilakukan pengeringan tongkol jagung selama \pm 7 hari sehingga biji kering dan dapat dipipil. Peubah yang diamati adalah karakter dan komponen hasil di lapangan dilakukan sebelum dan setelah panen dengan mengamati karakter - karakter sebagai berikut: Tinggi Tanaman (cm), Umur Bunga Jantan (hari), Umur Bunga Betina (hari), Anthesis Silking Interval (ASI), Leaf Area Index (LAI), dan Umur Panen (hari). Komponen hasil yang diambil adalah; panjang tongkol $(\mathrm{cm})$, diameter tongkol $(\mathrm{cm})$, bobot tongkol (g) dan bobot 1000 biji (g) dan hasil per petak $(\mathrm{kg})$.

Konversi hasil per petak ke hasil per hektar sebagai berikut:

$$
\begin{aligned}
& \text { Hasil }(\mathrm{kg} / \mathrm{ha}) \\
& =\frac{10000}{L P} \times \frac{100-K A}{100-15} \times B \times R
\end{aligned}
$$

Keterangan:

$\mathrm{KA}=$ Kadar Air biji saat panen (\%)

$\mathrm{LP}=$ Luas Panen $(\mathrm{m} 2)$

$\mathrm{B}=$ Bobot tongkol kupasan $(\mathrm{kg})$

$\mathrm{R}=$ Rendemen (Rata - rata "Shelling Percentage") atau dapat dihitung dengan membagi bobot pipilan/bobot tongkol (\%)

Pengolahan data pertumbuhan vegetatif, generatif dan komponen hasil dianalisis menggunakan uji $\mathrm{F}$ dengan selang kepercayaan $95 \%$. Jika terdapat pengaruh nyata maka dilakukan uji lanjut Beda Nyata Terkecil (BNT) atau Least Significant Difference (LSD) pada taraf $\alpha$ $=5 \%$ (Fisher, 1935). Uji korelasi juga digunakan untuk mengetahui keeratan hubungan antar karakter yang diuji. 


\section{HASIL DAN PEMBAHASAN Rukmana dan Yudirachman (2007)}

\section{Tinggi Tanaman}

Hasil penelitian pada Tabel 1 hibrida berkisar 1,5 m-2,0 m sedangkan menunjukkan beberapa genotype jagung jagung varietas genjah rata - rata $1 \mathrm{~m}$ calon hibrida umur genjah yang bahkan ada yang lebih pendek. berpengaruh nyata terhadap tinggi tanaman jagung. berpendapat bahwa tinggi tanaman jagung

Tabel 1. Rata - rata Tinggi Tanaman Jagung (cm) 3 Genotype Jagung Calon Hibrida Umur Genjah dan Varietas Pembanding Bima 7

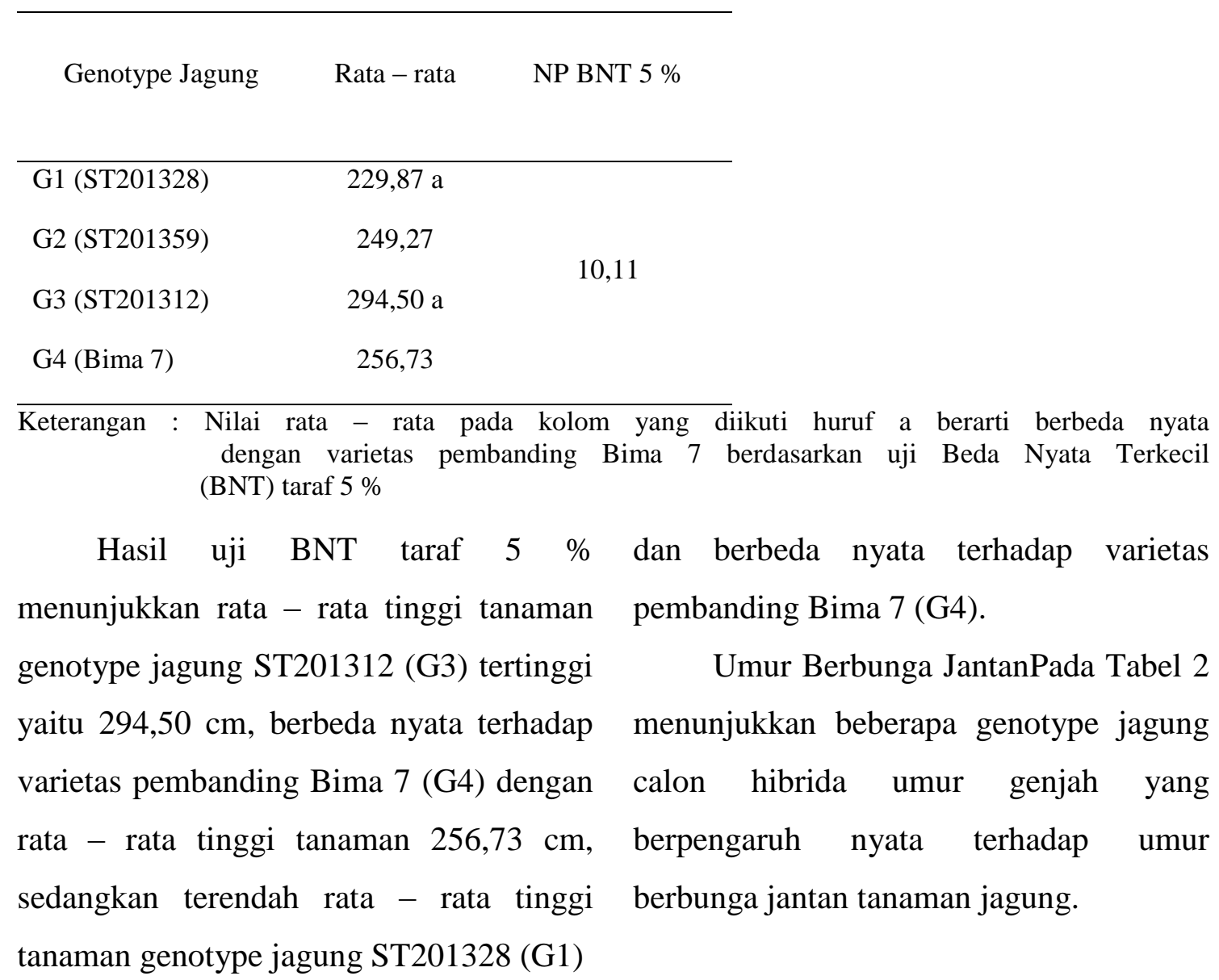


Tabel 2. Rata - rata Umur Berbunga Jantan (hari) 3 Genotype Jagung Calon Hibrida Umur Genjah dan Varietas Pembanding Bima 7

\begin{tabular}{lcc}
\hline \multicolumn{1}{c}{ Genotype Jagung } & Rata - rata & NP BNT 5\% \\
\hline G1 (ST201328) & 49,50 & \\
G2 (ST201359) & $50,00 \mathrm{a}$ & 0,31 \\
G3 (ST201312) & $51,67 \mathrm{a}$ & \\
G4 (Bima 7) & 49,67 &
\end{tabular}

Keterangan : Nilai rata - rata pada kolom yang diikuti huruf a berarti berbeda nyata dengan varietas pembanding Bima 7 berdasarkan uji Beda Nyata Terkecil (BNT) taraf $5 \%$..

Hasil uji BNT taraf $5 \%$, adalah genotype jagung ST201312 (G3) menunjukkan bahwa rata - rata umur yaitu 51,67 hst berbeda nyata dengan berbunga jantan tanaman jagung tercepat varietas pembanding Bima 7. Umur adalah genotype jagung ST201328 (G1) Berbunga Betina Berdasarkan Tabel 3, yaitu 49,50 hari setelah tanam (hst), tetapi beberapa genotype jagung calon hibrida tidak berbeda nyata dengan varietas umur genjah berpengaruh nyata terhadap pembanding Bima 7 (G4) yaitu 49,67. umur berbunga betina tanaman jagung.

Rata-rata umur berbunga jantan terlambat

Tabel 3. Rata - rata Umur Berbunga Betina (hari) 3 Genotype Jagung Calon Hibrida Umur Genjah dan Varietas Pembanding Bima 7

\begin{tabular}{lcc}
\hline Genotype Jagung & Rata - rata & NP BNT 5\% \\
& \\
\hline G1 (ST201328) & 50,67 a & \\
G2 (ST201359) & 52,00 a & 0,40 \\
G3 (ST201312) & 53,67 a & \\
G4 (Bima 7) & 51,67 &
\end{tabular}

Keterangan : Nilai rata - rata pada kolom yang diikuti huruf a berarti berbeda nyata dengan varietas pembanding Bima 7 berdasarkan uji Beda Nyata Terkecil (BNT) taraf $5 \%$.

Hasil uji BNT taraf 5\%, betina (hari) genotype jagung ST201328 menunjukkan rata - rata umur berbunga (G1) tercepat dalam mengeluarkan bunga 
betina yaitu 50,67 hst, berbeda nyata $60 \mathrm{~cm}$ x $20 \mathrm{~cm}(\mathrm{~J} 1)$ rata - rata LAI terhadap varietas pembanding Bima 7 5,58.Menurut Tetio-Kangko dan Gardner yaitu 51,67 hst, sedangkan genotype (1998), peningkatan Leaf Area Index pada jagung terlambat mengeluarkan bunga batas tertentu akan meningkatkan betina adalah genotype jagung ST201312 produksi jagung. Jarak tanam $50 \mathrm{~cm}$ x 20 (G3) rata - rata 53,67 hst berbeda nyata cm menunjukkan LAI lebih tinggi karena dan lebih lambat mengeluarkan bunga tanaman jagung rapat sehingga terjadi betina dibandingkan varietas Bima 7 . peningkatan populasi tanaman jagung,

Leaf Area Index (LAI) Pada Tabel 5, menunjukkan beberapa genotype kemungkinan indeks luas daun atau Leaf Area Index (LAI) lebih besar pada fase jagung calon hibrida umurgenjah dan silking, yang memungkinkan tanaman jarak tanam berbeda berpengaruh nyata untuk menangkap lebih banyak sinar terhadap Leaf Area Index tanaman jagung. Hasil uji BNT taraf $5 \%$ menunjukkan bahwa genotype ST201312 (G3) memberikan rata - rata Leaf Area Index (LAI) tertinggi genotype jagung ST201312 (G3) berbeda nyata terhadap varietas pembanding Bima 7 (G4) rata rata LAI 5,92 dan genotype jagung yang matahari. Semakin banyak tanaman per satuan luas maka semakin tinggi LAI sehingga persen cahaya yang diterima oleh bagian tanaman yang lebih rendah dan sedikit karena akibat adanya penghalang cahaya oleh daun - daun di atasnya (Cox, 1996; Hanafi, 2005; Tollenaar dan Augilera, 1992).

berbeda nyata terhadap varietas pembanding lainnya yaitu genotype jagung ST201328 (G1) rata - rata 6,48. Sedangkan perlakuan jarak tanam hasil uji BNT taraf $5 \%$ pada tabel 5 jarak tanam $50 \mathrm{~cm}$ x $20 \mathrm{~cm}(\mathrm{~J} 2)$ dengan rata- rata LAI 6,83 berbeda nyata terhadap jarak tanam 
Tabel 4. Rata - rata Leaf Area Index 3 Genotype Jagung Calon Hibrida Umur Genjah dan Varietas Pembanding Bima 7 pada Berbagai Jarak Tanam

\begin{tabular}{|c|c|c|c|c|}
\hline \multirow{2}{*}{ Genotype Jagung } & \multicolumn{2}{|c|}{ Jarak Tanam } & \multirow{2}{*}{ Rata - rata } & \multirow{2}{*}{ NP BNT $5 \%$} \\
\hline & $\mathrm{J} 1(60 \mathrm{~cm} \times 20 \mathrm{~cm})$ & $\mathrm{J} 2(50 \mathrm{~cm} \times 20 \mathrm{~cm})$ & & \\
\hline G1 (ST201328) & 5,85 & 7,11 & $6,48 \mathrm{a}$ & \\
\hline G2 (ST201359) & 4,97 & 5,98 & 5,48 & \\
\hline G3 (ST201312) & 6,09 & 7,09 & $6,59 \mathrm{a}$ & 0,39 \\
\hline G4 (Bima 7) & 5,40 & 6,43 & 5,92 & \\
\hline Rata - rata & $5,58 \mathrm{y}$ & $6,65 x$ & & \\
\hline
\end{tabular}

Keterangan : Nilai rata - rata pada kolom yang diikuti huruf $\mathrm{x}$ berarti berbeda nyata dengan varietas pembanding Bima 7 berdasarkan uji Beda Nyata Terkecil (BNT) taraf $5 \%$

Nilai rata - rata pada baris yang Hasil uji BNT taraf $5 \%$ rata - rata umur diikuti huruf $\mathrm{x}$ berarti berbeda nyata panen genotype jagung calon hibrida terhadap jarak tanam $60 \mathrm{~cm}$ x $20 \mathrm{~cm}$ umur genjah, menunjukkan umur panen berdasarkan uji Beda Nyata Terkecil jagung dipengaruhi oleh suhu, setiap (BNT) taraf $5 \%$. Umur Panen Pada Tabel kenaikan tinggi tempat $50 \mathrm{~m}$ dari 6, menunjukkan beberapa genotype permukaan laut, umur panen akan mundur jagung calon hibrida umur genjah dan satu hari (Hyene, 1987; Irianto et al., jarak tanam berbeda berpengaruh nyata 2000). Lokasi penelitian jagung tersebut terhadap umur panen tanaman jagung. terletak pada ketinggian $55 \mathrm{~m} \mathrm{dpl}$.

Tabel 5. Rata - rata Umur Panen (hst) 3 Genotype Jagung Calon Hibrida Umur Genjah dan Varietas Pembanding Bima 7

\begin{tabular}{ccc}
\hline Genotype Jagung & Rata - rata & NP BNT 5 \% \\
& & \\
\hline G1 (ST201328) & $82,83 \mathrm{a}$ & \\
G2 (ST201359) & $85,00 \mathrm{a}$ & 0,23 \\
G3 (ST201312) & $85,00 \mathrm{a}$ & \\
G4 (Bima 7) & 83,33 &
\end{tabular}

Keterangan : Nilai rata - rata pada kolom yang diikuti huruf a berarti berbeda nyata dengan varietas pembanding Bima 7 berdasarkan uji Beda Nyata Terkecil (BNT) taraf $5 \%$ 
Genotype jagung ST201328 7 dengan rata - rata umur panen 83,33 memiliki umur panen rata - rata 82,83 hari. Komponen Hasil Berdasarkan Tabel hari setelah tanam (hst) yang termasuk 7 menunjukkan bahwa beberapa genotype genotype yang berumur genjah umur jagung dan jarak tanam berbeda panen antara 75 - 95 hari (Azrai, 2013) memberikan interaksi yang berpengaruh sedangkan Genotype ST201312 lebih nyata terhadap panjang tongkol tanaman lambat panen rata - rata 85 hari berbeda jagung. nyata terhadap varietas pembanding Bima

Tabel 6. Rata - rata Panjang Tongkol Kombinasi Perlakuan 3 Genotype Jagung Calon Hibrida Umur Genjah dan Varietas Pembanding Bima 7 pada Jarak Tanam yang Berbeda

\begin{tabular}{lcc}
\hline \multirow{2}{*}{ Genotype Jagung } & \multicolumn{2}{c}{ Jarak Tanam } \\
\cline { 2 - 3 } & $\mathrm{J} 1(60 \mathrm{~cm} \times 20 \mathrm{~cm})$ & $\mathrm{J} 2(50 \mathrm{~cm} \times 20 \mathrm{~cm})$ \\
\hline G1 (ST201328) & 17,40 & $17,40 \mathrm{a}$ \\
G2 (ST201359) & 17,37 & $17,30 \mathrm{a}$ \\
G3 (ST201312) & 18,07 & 15,93 \\
G4 (Bima 7) & 16,97 & 15,43 \\
\hline BNT 5 \% & & \\
\hline
\end{tabular}

Keterangan : Nilai rata - rata pada kolom yang sama diikuti huruf a berarti berbeda nyata dengan varietas pembanding Bima 7 berdasarkan uji Beda Nyata Terkecil (BNT) taraf $5 \%$

Hasil uji BNT taraf $5 \%$, sedangkan interaksi genotype jagung menunjukkan rata - rata panjang tongkol ST201328 pada jarak tanam $50 \mathrm{~cm}$ x 20 interaksi antara genotype jagung calon $\mathrm{cm}$ (G1J2) memiliki panjang tongkol ratahibrida umur genjah dan jarak tanam rata $17,40 \mathrm{~cm}$ berpengaruh nyata terhadap berbeda tertinggi genotype jagung varietas pembanding Bima 7 pada jarak ST201312 pada jarak tanam $60 \mathrm{~cm} \times 20$ tanam $50 \mathrm{~cm} \times 20 \mathrm{~cm}(\mathrm{G} 4 \mathrm{~J} 2)$ atau cm (G3J1) rata-rata panjang tongkol terendah rata - rata panjang tongkolnya 18,07 cm, tidak berbeda nyata terhadap yaitu 15,43 cm.Genotype jagung varietas pembanding Bima 7 pada jarak ST201312 ini mempunyai karakteristik tanam $60 \mathrm{~cm} \times 20 \mathrm{~cm}$ (G4J1) dengan keragaan batang yang panjang, kanopi panjang tongkol rata - rata $16,97 \mathrm{~cm}$ maupun posisi daun atau sudut daun yang 
tegak (erect) sehingga tidak saling ditanam dengan populasi yang tinggi. menutupi cocok ditanam pada jarak tanam Kepadatan yang tinggi diharapkan dapat yang rapat, karena tanaman lebih leluasa memberikan hasil yang tinggi pula.Pada dan kanopi tidak saling menutupi dalam Tabel 8, menunjukkan beberapa genotype menangkap sinar matahari. Nuning et al. jagung calon hibrida umur genjah dan (2007), menyatakan jagung dengan tipe jarak tanam berbeda berpengaruh nyata daun erect memiliki kanopi kecil dapat terhadap umur panen tanaman jagung. Tabel 7. Rata - rata Diameter Tongkol $(\mathrm{cm})$ Tanaman Jagung 3 Genotype Calon Hibrida Umur Genjah dan Varietas Pembanding Bima 7

Genotype Jagung Rata - rata NP BNT $5 \%$

\begin{tabular}{lcc}
\hline G1 (ST201328) & 4,35 a & \\
G2 (ST201359) & 4,49 & 0,11 \\
G3 (ST201312) & 4,27 a & \\
G4 (Bima 7) & 4,53 &
\end{tabular}

Keterangan : Nilai rata - rata pada kolom yang diikuti huruf a berarti berbeda nyata dengan varietas pembanding Bima 7 uji Beda Nyata Terkecil (BNT) taraf $5 \%$

Rata - rata diameter, hasil uji BNT ditanam pada jarak tanam yang berbeda taraf $5 \%$, genotype jagung yang memilki hasil sidik ragam tidak berpengaruh nyata. diameter tertinggi yaitu varietas Berdasarkan Gambar 1 memperlihatkan pembanding Bima 7 (G4) dengan bobot tongkol jagung tertinggi yaitu diameter 4,53 cm berbeda nyata terhadap genotype jagung ST201359 pada jarak genotype jagung ST201328 (G1) rata- tanam $60 \mathrm{~cm}$ x $20 \mathrm{~cm}$ (G2J1) yaitu 193,66 rata diameter tongkol $4,35 \mathrm{~cm}$ dan $\mathrm{g}$, juga lebih tinggi dibandingkan dengan genotype jagung ST201312 (G3) varietas pembanding Bima 7 baik jarak sekaligus memilki diameter tongkol tanam $60 \quad \mathrm{~cm} \quad \mathrm{x} \quad 20 \quad$ (G4J1) 175,53 terendah rata - rata $4,27 \mathrm{~cm}$. grammaupun $50 \mathrm{~cm}$ x $20 \mathrm{~cm}(\mathrm{G} 4 \mathrm{~J} 2)$

Bobot tongkol beberapa genotype 160,83 gram. jagung calon hibrida umur genjah yang 


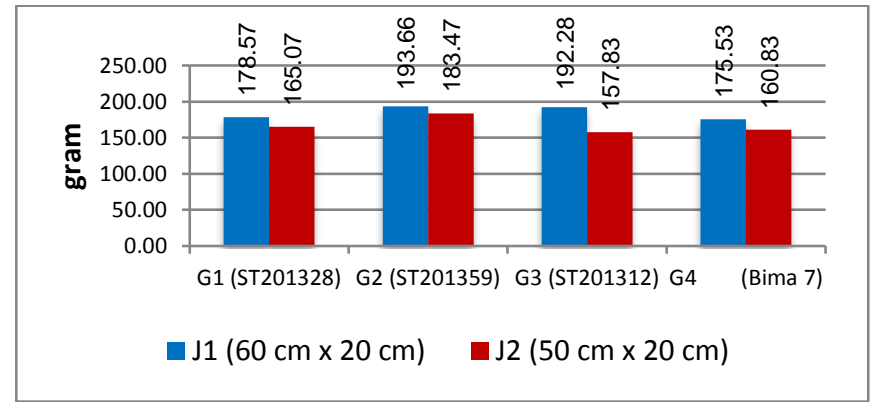

Gambar 1. Rata - rata bobot tongkol (g) genotype jagung calon hibrida umur genjah dan varietas pembanding Bima 7 pada jarak tanam yang berbeda.

Hasil per hektar beberapa genotype hasil pipilan kering 10,58 ton ha-1, lebih jagung calon hibrida umur genjah pada tinggi dibandingkan dengan varietas jarak tanam berbeda berdasarkan sidik pembanding Bima 7 dengan jarak tanam ragam tidak berpengaruh nyata. Pada $60 \mathrm{~cm}$ x 20 (G4J1) diperoleh rata - rata Gambar 4, menunjukkan rata- rata hasil hasil pipilan kering 8,47 ton ha-1 per hektar genotype jagung calon hibrida sedangkan pada jarak tanam $50 \mathrm{~cm}$ x 20 umur genjah yang ditanam pada berbagai $\mathrm{cm}(\mathrm{G} 4 \mathrm{~J} 2)$ diperoleh rata - rata hasil jarak tanam tertinggi genotype pipilan kering 8,22 ton $\mathrm{ha}^{-1}$.

ST201312 (G3J2) diperoleh rata - rata

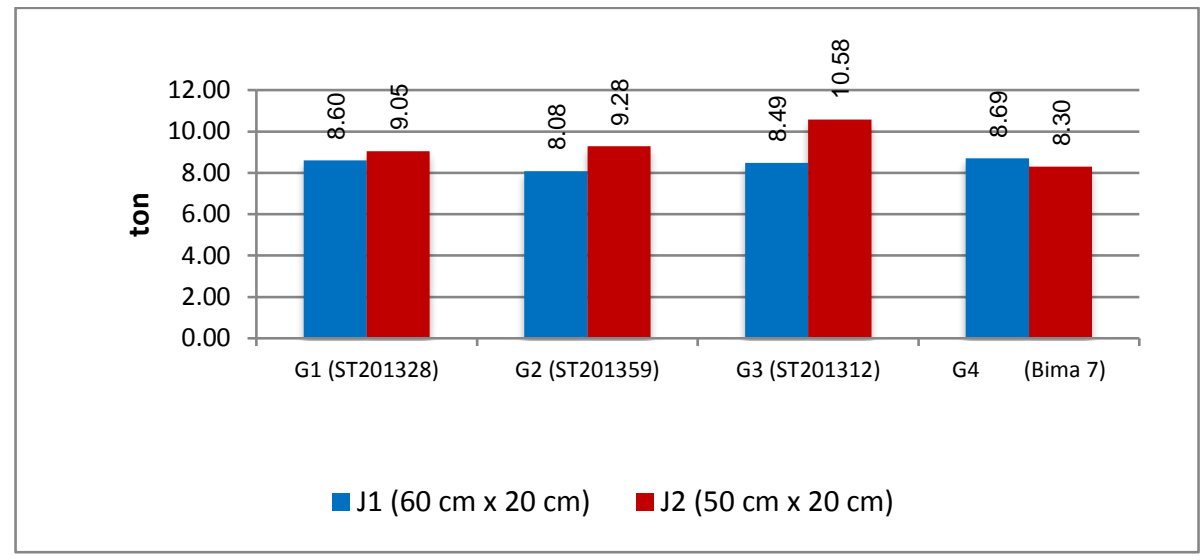

Gambar 2. Rata - rata hasil per hektar (ton) genotype jagung calon hibrida umur genjah dan varietas pembanding Bima 7 pada jarak tanam yang berbeda

\section{KESIMPULAN}

Berdasarkan hasil penelitian yang dilakukan maka dapat disimpulkan antara lain: Genotype Jagung ST201328 merupakan jagung yang berumur genjah, mempunyai penampilan tanaman yang terpendek, umur berbunga jantan maupun betina tercepat, Anthesis Silking Interval 
(ASI) terkecil, umur panen tercepat, dan panjang tongkol yang lebih panjang. Genotype ST201312 mempunyai penampilan tanaman tertinggi, ASI terbesar, Leaf Area Index (LAI) terbesar dan tongkol terpanjang. Jarak tanam 50 $\mathrm{cm}$ x $20 \mathrm{~cm}$ diperoleh Leaf Area Index yang tinggi. Rata - rata produksi biji kering tertinggi pada jarak tanam $50 \mathrm{~cm} \times 20 \mathrm{~cm}$ untuk semua genotype jagung yang diuji. Interaksi yang terjadi antara genotype jagung ST201328 dan jarak tanam $60 \mathrm{~cm}$ x $20 \mathrm{~cm}$ diperoleh tongkol terpanjang yaitu 18,07 $\mathrm{cm}$ dan berbeda nyata dengan varietas pembanding Bima 7. Genotype jagung ST201312 pada jarak tanam $50 \mathrm{~cm} \times 20$ $\mathrm{cm}$ diperoleh hasil pipilan kering tertinggi yaitu sebesar 10,58 ton $\mathrm{ha}^{-1}$.

\section{DAFTAR PUSTAKA}

Adger, N.W., Nigel W.A. and Emma L.T. 2005. Successful Adaptation To Climate Change Across Scales. Global Environmental Change 15:77-86. www.Elsevier.Com/Locate/Gloenvc $\underline{\text { ha }}$

Arifin, Z. 2011. Kajian Adaptasi Galur Harapan Jagun Berumur Genjah Serta Toleran Penyakit Bulai Dan Pemupukan N Rendah. Berk. Penel. Hayati Edisi Khusus: 7A (113-117. BPTP Jawa Timur.
Azrai, M. 2013. Jagung hibrida genjah: Prospek pengembangan menghadapi perubahan iklim. Iptek Tanaman Pangan 8(2):90 - 96.

Azrai, M., Djamaluddin, Syuryawati, Firmansyah, I.U. dan Efendy, R. 2009. Pembentukan jagung hibrida umur genjah $( \pm 80$ hari $)$ toleran kekeringan dan hasil tinggi (>8 t/ha). Laporan Akhir Penelitian Sinta. Direktorat Jenderal Pendidikan Tinggi, Block Grand Akun 5721 TA. 53p.

Balitbang Pertanian. 2011. Pedoman umum adaptasi perubahan iklim sektor pertanian.

Berzsenyi, Z. and Tokatlidis, I.S. 2012. Density-dependence rather maturity determines hybrid selection in dryland maize production. Agron. J. 104:331-336. doi:10.2134/agronj2011.0205

BPS (Badan Pusat Statistik). 2016. Produksi, Luas Panen dan Produktivitas Jagung di Provinsi Sulawesi Selatan. bps.go.id. Badan Pusat Statistik. Makassar. Sulawesi Selatan (Diakses 17 Desember 2016).

Coulter, J. and Van Roekel, R. 2009. Selecting corn hybrids for grain production. University of Minnesota.

Coulter, J.A., Nafziger, E.D., Janssen, M.R. and Pedersen, P. 2010. Response of $\mathrm{Bt}$ and near-isoline corn hybrids to plant density. Agron. J. 102:103 - 111 .

Cox, W.J. 1996. Whole-plant physiological and yield responses of 
maize to plant density. Agron. J. 88:489 - 496 .

Dourado, N.D., Palhares, M., Vieira, P.A., Manfron, P.A., Medeiros, S.L.P. and Romano, M.R. 2003. Efeito da população de plantas e do espaçamento sobre a produtividade de milho. Rev Bras Milho Sorgo. 2(3): $63-77$.

Gardner, P.F., Pearce, B.R., and Mitchell, R.L. 1996. Fisiologi Tanaman Budidaya. Terjemahan oleh Hemawati S. Universitas Indonesia. Jakarta.

Hanafi, M.A. 2005. Pengaruh Kerapatan Tanaman terhadap Pertumbuhan dan Hasil Tiga Kultivar Jagung (Zea mays L) untuk Produksi Jagung Semi. Fakultas Pertanian Universitas Brawijaya. Malang.

Hyene, K. 1987. Tumbuhan berguna Indonesia-I. Balai Penelitian dan Pengembangan Kehutanan, Departemen Kehutanan Bogor.

IFPRI (International Food Policy Research Institute). 2000. 2020 Projections. IFPRI, Washington, DC

Irianto, G., Le I. Amien, dan Sumarni. 2000. Keragaman iklim sebagai peluang diversifikasi. Sumber Lahan Indonesia dan Pengelolaannya. Pusat Penelitian Pertanian Agroklimat: 67 - 95 .

Kementrian Perindustrian. 2016. Prediksi Kebutuhan Jagung di Indonesia tahun 2017. http://www.kemenperin.go.id/artikel /13892/2016,-RI-Impor-Jagung-2,4Juta-Ton. Diakses 28 April 2017
Maddonni, G.A., Otegui, M.E. and Cirilo, A.G. 2001. Plant population density, row spacing and hybrid effects on maize canopy architecture and light attenuation. Field Crop Res. 71(3): $183-193$.

Nuning, A.S., Syafruddin, Efendi, R. Dan Sunarti, S. 2007. Morfologi Tanaman dan Fase Pertumbuhan Jagung. Pusat Penelitian dan Pengembangan Tanaman Pangan, Departemen Pertanian. Jakarta. Hal $16-41$

Priyanto, S.B., Iriani, R.N.dan Takdir M.A. 2016. Stabilitas Hasil Jagung Varietas Hibrida Harapan Umur Genjah. Balai Penelitian Tanaman Serealia. Maros, Sulawesi Selatan, Indonesia. E-mail: s.bambangpriyanto@gmail.com. Hal $126-132$

Resiworo, D.J.S. 2012. Pengendalian Gulma dengan Pengaturan Jarak Tanam dan Cara Penyiangan Kedelai. Prosiding Konferensi Himpunan Ilmu Gulma Indonesia. Ujung Pandang. Hal. 247 - 250. Pada Produksi Jagung Manis (Zea mays saccaratha) pada Tanah Entisols.

Robles, M., Ciampitti, I.A. and Vyn, T.J. 2012. Responses of maize hybrids to twin-row spatial arrangements at multiple plant densities. Agron. J. 104:1747 - 1756.

Rukmana, R. dan Yudirachman, H. 2007. Budidaya Jagung, Pasca Panen dan Penganekaragaman Panan. Penerbit Aneka Ilmu. Semarang.

Sadeghi, M., Naderi, A., Lak, S., Fathi, G.A. 2012. Evaluation of plant population density on growth, grain 
yield and yield components of four maize hybrids. Adv Environ Biol. 6(1): $327-333$.

Subaedah, St., A.Aladin dan Nirwana. 2015. Fertilization of Nitrogen, Phosphor and Application of Green Manure of Crotalaria juncea In Increasing Yield of Maize In Marginal Dry Land. Agriculture and Agricultural Science Procedia 9:20-25

Subaedah, St., A.Takdir, Netty, Hidrawati. 2016. Evaluaion of potential production of maize genotypes of early maturity in rainfed lowland. J.of Biological, Biomoleculer, Agricultural, Food and Biotechnological Engineering 10 (10):584-587.

Sudjana, A.A., Rifin dan Setiyono, R. 1998. Tanggapan Beberapa Varietas Jagung terhadap Naiknya Tingkat Kepadatan Tanaman. Pusat Penelitian dan Pengembangan Tanaman Pangan. Bogor. 6:97 100.

Sumarni, N., Rosliani, R., Suwandi. 2012. Optimasi Jarak Tanam dan Dosis Pupuk NPK untuk Produksi Bawang Merah dari Benih Umbi Mini di Dataran Tinggi. Jurnal hortikultura. 22(2): $148-155$.

Suprapto dan Nyoman, A.J. 2000. Berbagai Masukan Teknologi untuk Meningkatkan Produktivitas Lahan Marginal. Laporan Akhir Penelitian SUT Diversivikasi Lahan Marginal di Kecamatan Gerokgak. Buleleng Dalam No. Agdex 100/16. No. Seri Il/Tanaman/z\}\}DD Oktober 2000. Instalasi Penelitian dan Pengkaiian Telmologi Pertanian Denpasar: Bali.
Suryana, A., Darmadjati, D.S., Subandi, Kariyasa, K., Zubachtirodin dan Saenong, S. 2005. Prospek dan Arah Pengembangan Agribisnis Jagung. 